\title{
Physical and Mechanical Properties of Lightweight Expanded Clay Aggregate (LECA)
}

\author{
Azhani Zukri ${ }^{1,2}$, Ramli Nazir², Khairun Nissa Mat Said ${ }^{2}$, Hossein Moayedi ${ }^{3}$ \\ ${ }^{1}$ Fakulti Kejuruteraan Awam \& Sumber Alam, Universiti Malaysia Pahang, Lebuhraya Tun \\ Razak, Gambang, Pahang, Malaysia \\ ${ }^{2}$ Centre of Tropical Geoengineering, Fakulti Kejuruteraan Awam, Universiti Teknologi \\ Malaysia, Skudai, Johor, Malaysia \\ ${ }^{3}$ Department of Civil Engineering, Kermanshah University of Technology Kermanshah, Iran
}

\begin{abstract}
Lightweight aggregate is the generic name of a group of aggregates having a relative density lower than normal aggregates (natural sand, gravel, and crushed stone), sometimes is referred to as low density aggregate. Depending on the source and the method of production, lightweight aggregates exhibit considerable differences in particle shape, texture and properties. Lightweight expanded clay aggregate (LECA) is among the common lightweight materials that have been applied successfully in civil engineering works. Many studies have been conducted to investigate the performances of LECA used in structural and geotechnical applications. They are favourable materials used in projects where weight is an issue because the materials can help reduce dead loads and lateral forces by more than half in installations over structures and those with soft soils. LECA is an eco-friendly nature-based waste product that combines the same benefits as brick tiles. LECA is indestructible, non-combustible, and impervious to attack by dry-rot, wet-rot and insects. This paper focused on the properties of LECA aggregates supplied by LEXCA Sdn. Bhd. through laboratory tests in accordance to the standard specifications. The properties of several LECA produced from different country and production plants are also reviewed for comparative purpose. In addition, the material properties evaluated from previously conducted research also was discussed. It was found that, even though LECA was produced from the same raw materials, it has certain range of property values. The properties of LECA shows their suitability and potential for replacing natural aggregates in many civil engineering works. It is hoped that, the properties presented in this paper could help others who conduct study especially numerical analysis using LECA as geotechnical materials.
\end{abstract}




\section{Introduction}

Lightweight aggregate (LWA) has a long track record of quality and performance in construction industry. Since its development in the early nineteen hundreds, LWA produced by the rotary kiln process has been used extensively in asphalt road surfaces, concrete bridge decks, high-rise buildings, concrete precast and pre stressed elements, concrete masonry and geotechnical applications. Naturally available raw materials suitable for manufacturing lightweight mineral granules are pumice, perlite, vermiculite, expandable clay and slate. The quality of LWA results from a carefully controlled manufacturing process. In a rotary kiln, selectively mined shale, clay or slate is combusted (firing) in excess of $2000^{\circ} \mathrm{F}$. The LWA material is then processed to precise gradations. The result is a high quality, lightweight aggregate that is inert, durable, tough, stable, highly insulated, and free draining. Moreover, the expanded clay production process allows nondangerous waste materials to be reclaimed and thereby avoids the necessity to dispose of them in a landfill or dump - this benefits the environment and also offers economic advantages. LWA gives designers greater flexibility in creating solutions to meet the challenges of dead load, terrain, seismic conditions, construction schedules and budgets in today's market place.

Clay ceramsite, is a kind of artificial particles of a ceramic texture. Clay, loam, etc. as the main raw materials, through granulation processing, burning swelling, become more than $5 \mathrm{~mm}$ diameter light coarse aggregate known as the clay ceramsite. Ceramic clay has the nature of economic and practical, energy-saving environmental protection, with lightweight, high strength, low water absorption, thermal insulation, antifreeze and corrosion characteristics, therefore a large numbers are used in the preparation of building high-rise concrete structure, roof slope, thermal insulation, sewage disposal, landscaping, soilless culture and other fields.

Expanded clay shale (ECS) and light weigh expanded clay aggregate (LECA) are among the common lightweight materials that have been applied successfully in geotechnical application. LECA is known as Brazilian lightweight aggregate in Brazil and Azerit in Azerbaijan. LECA is a natural product containing no harmful substances. It is inert with a neutral $\mathrm{pH}$ value, resistant to frost and chemicals, will not break down in water, is non-biodegradable, non-combustible and has excellent sound and thermal insulation properties. Lightweight aggregate can reduce the weight of compacted geotechnical fills by up to one-half. This material is currently being used in many civil engineering works due to its low weight, high strength and favourable drainage characteristics. Previous study shows that the ECS and LECA have been used as filler material for road embankment construction and filling behind retaining wall, airport pavement subgrades, planting and storm water drainage system. Such materials have been used since the 1960s in many civil engineering projects and particularly for geotechnical applications [1]. 
There are many studies using LECA materials to improve the structural and/or geotechnical behaviours of building structures. The research on lightweight aggregate behaviours in structural works has been established by many researchers such as Pioro L.P. (2004), Bogas (2012), Yazdani, Payam Shafigh, J. Alexandre Bogas et al. (2014), M. D. N. Laura Maria Mello Saraiva Caldeira, C. S. Murat Emre Dilli et al. (2015), Abhijitsinh Parmar et al., Tao Wu et al. (2016)[2-12].

A.J. Valsangkar et al. (1987) conducted a study to investigate whether the replacement of normal weight aggregate by lightweight aggregate would affect the overall road stiffness of road construction on the peat soil using road structure model developed by Douglas et al. (1985) and modified by Addo (1986) [13].

J. Gorniak et al. (2015) introduced a new type of mechanically stabilized earth (MSE) structure composed of geosynthetic tubes filled with expanded clay lightweight aggregate and backfilled with geosynthetic reinforcement. Experimental works conducted show the influence of the geosynthetic stiffness on the behavior of the tube in terms of loading capacity, volume variation and cross-section of the tube. The researcher found that the agreement between theoretical analyses and experimental results was reasonably good and can be formally accepted for a given volume variation of the geosynthetic tube filled with expanded clay lightweight aggregate [14].

Department of Transportation, California presented a report on the investigation of seismic performances of MSE walls with two alternative backfill materials: tire derived aggregates (TDA) and lightweight aggregates (LWA) using twodimensional numerical analysis (using Plaxis) and then validated through small-scale shake table testing. It was concluded that when properly designed, MSE walls with TDA backfill can sustain strong seismic shaking without excessive deformation and lateral spreading [15].

The earliest study on properties of Lightweight Expanded Clay aggregates was conducted by O. Arioz et al. (2008) where two types of LECA were produced from two types of clays having different chemical compositions. After the production, the physical and microstructural properties of the aggregates were determined. The effect of clay type, firing temperature, amount and type of a pore forming agent on the water absorption, specific gravity, pore structure, and surface texture of the expanded granules were examined. Conclusively, it was found that the type of clay, the type and amount of pore forming agent, and the firing temperature were very important for the properties of LECA [16]. Similar study also has been done to produce LECA in Iraq for structural application [17].

Light expanded clay aggregate has been produced in more than twenty countries with different brand names. For example Italy, Denmark, Switzerland, Norvey, Germany, Finland, Portugal, U.K, and Iran with brand of LECA, Russia, Poland, Sweden and China with the brand of Keramzite, South Africa with the brand of Argex and Spain 
with the brand of Liapour. Examples of LECA's manufacturer around the world are MEXCA IN Iran, Optiroc in Norway, Finland, Estonia and Swedan, GEO LECA, ESCS, GBC in India, Norlite, Techniclay and so on. Even though it was produced from the same raw materials (clay), the properties of LECA has certain range of values. Different type and size range of aggregate is produced for different uses. This paper focused on the properties of LECA aggregates supplied by LEXCA Sdn. Bhd. through laboratory tests in accordance to the standard specifications. The properties of several LECA produced from different country and production plants are also reviewed for comparative purpose.

\section{Methodology}

In this study, the properties of materials were tested according to the British Standard and/or the American Society of Testing Material (ASTM), based on the suitability and availability of the equipment in the laboratory for the respective tests. The LECA aggregate particles used for laboratory tests passed the $20 \mathrm{~mm}$ BS sieve size but retained at $14 \mathrm{~mm} \mathrm{BS}$ sieve size. This size range is chosen so that it is similar to coarse aggregate particles since the function of LECA is to substitute the aggregate in geotechnical works such as filler materials in stone column construction and as replacement materials for soil stabilization.

\section{Physical Properties of LECA}

\subsection{Particle Shape and Surface Texture}

In terms of their dimensions, the expanded clay particles can be classified as gravels. The study of the physical and hydro mechanical properties of the particles is not common when working with natural gravels or normal aggregates. However, when dealing with lightweight aggregate, particles characterization is essential in order to obtain the necessary information regarding their engineering behaviour as a particulate material. Depending on the source and the method of production, lightweight aggregates exhibit considerable differences in particle shape and texture. Shapes may be cubical, rounded, angular, or irregular, while the textures may range from fine pore, relatively smooth skins to highly irregular surfaces with large exposed pores. Each particles consists of the typical features of lightweight aggregates which are a highly porous core containing a rather broad distribution of pore size and shape and a denser outer shell. Figure 1 shows the Lightweight Expanded Clay Aggregate (LECA) used in experimental work of this study. 


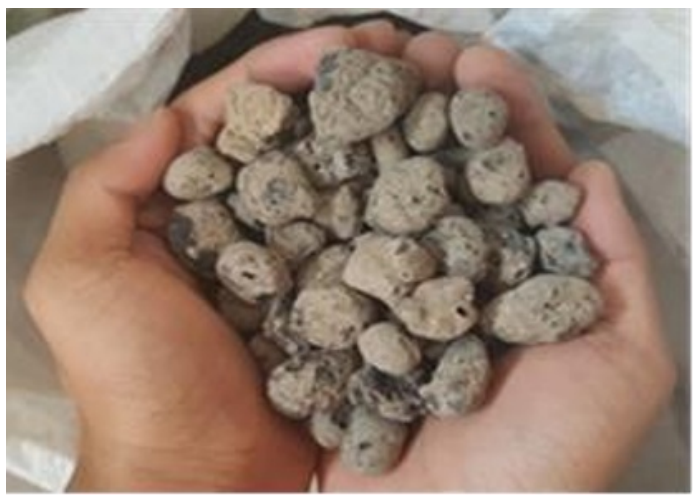

Fig 1: Lightweight Expanded Clay Aggregates (LECA)

\subsection{Sieve analysis}

A sieve analysis (or gradation test) is a practice or procedure commonly used in civil engineering to assess the particle size distribution (also called gradation) of a granular material. LECA is divided into several grain distribution sizes from the factory for different applications. For most geotechnical applications the grain grades mostly used are 10 to $20 \mathrm{~mm}$ and 20 to $30 \mathrm{~mm}$. There are two different batches were tested in the laboratory. Most of the sample from first batch tested, the grain grades was found to be 5 to $20 \mathrm{~mm}$. Based on the BS1377:1990, LECA is classified as coarse grained soil. The average coefficient of uniformity, $\mathrm{Cu}$ calculated is approximately 4.05 while the average coefficient of curvature, Cc is approximately 2.30 . From Unified Soil Classification System (USCS), LECA can be classified as well graded where the criteria $\mathrm{Cu}>4 \& 1<\mathrm{Cc}<3$ has been met. However, the grading of materials in second batch was found to be uniformly graded granular material. Figure 2 shows the particle size distribution of LECA aggregates according to ASTM C136.

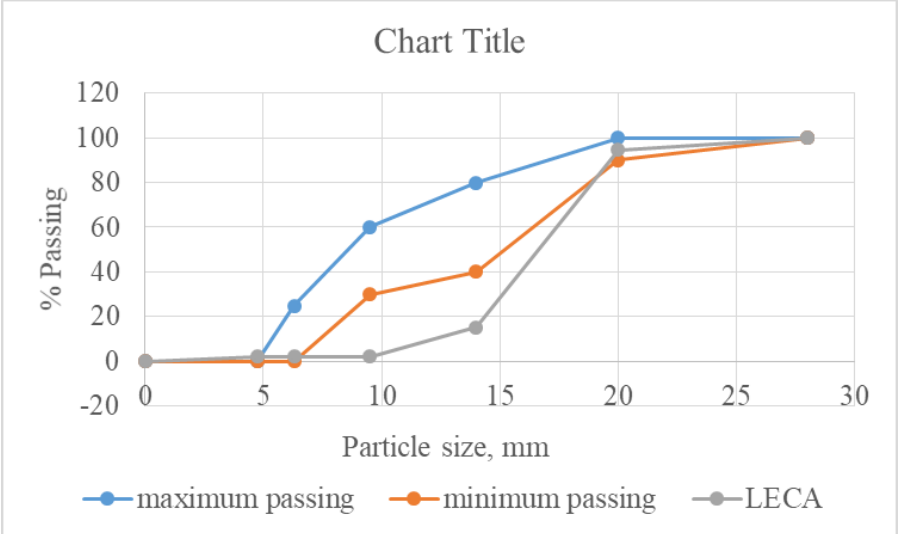

Fig. 2: Particle size distribution of LECA

\subsection{Bulk Density of LECA Aggregate}


Aggregate bulk density is defined as the ratio of the mass of a given quantity of material and the total volume occupied by it. This volume includes the voids between, as well as the pores within the particles. Bulk density is a function of particle shape, density, size, grading, and moisture content, as well as the method of packing the material (loose, vibrated, rodded) and varies not only for different materials, but for different sizes and gradations of a particular material. In general, the smaller the lightweight aggregate particle size, the higher is the density. The test was conducted based on BS 812-2:1995 and ASTM C127-01. Loose bulk density for LECA determined is $266 \mathrm{~kg} / \mathrm{m}^{3}$ while rodded bulk density calculated is $293 \mathrm{~kg} / \mathrm{m}^{3}$, which is shows that $10 \%$ volume reduction by compaction.

Research projects conducted by the Tomsk Polytechnic University (Russian Federation) in cooperation with the Bauhaus University Weimar (Germany) are dealing with the development of LWA from new raw materials sources. According to A. Mueller (2008), lightweight aggregates were produced from two main sources either from natural or waste materials. Natural raw materials suitable for manufacturing lightweight mineral granules are pumice, perlite, vermiculite, expandable clay and slate while, waste materials used to produce LWA are recycled glass, fly ash, crushed sands, and mineral foam granules and so on. Table 1 shows the typical properties of LWA manufactured from natural and waste materials [18]. The table demonstrated that the variety of chemical constituents and the expanding agent used in lightweight aggregate production contribute to various range of density value.

Table 1. Typical properties of LWA manufactured from natural and waste materials

\begin{tabular}{|c|c|c|c|c|c|c|}
\hline \multirow{2}{*}{$\begin{array}{c}\text { Typical } \\
\text { properties of } \\
\text { lightweight } \\
\text { aggregates }\end{array}$} & $\begin{array}{c}\text { Lightweight aggregates } \\
\text { from natural raw } \\
\text { materials }\end{array}$ & \multicolumn{3}{|c|}{ Lightweight aggregates from waste materials } \\
\cline { 2 - 6 } & $\begin{array}{c}\text { Perlite and } \\
\text { vermiculate }\end{array}$ & LECA & $\begin{array}{c}\text { Granules of } \\
\text { recycled } \\
\text { glass }\end{array}$ & $\begin{array}{c}\text { Granules } \\
\text { from } \\
\text { crushed } \\
\text { sands }\end{array}$ & $\begin{array}{c}\text { Mineral foam } \\
\text { granules }\end{array}$ & $\begin{array}{c}\text { Fly ash and } \\
\text { adjustment } \\
\text { components }\end{array}$ \\
\hline $\begin{array}{c}\text { Firing } \\
\text { temperature } \\
\text { C) }\end{array}$ & about 900 & $1100-$ & $750-900$ & $1000-1080$ & $<1000$ & $1000-1300$ \\
\hline $\begin{array}{c}\text { Bulk density } \\
\left(\mathrm{kg} / \mathrm{m}^{3}\right)\end{array}$ & $32-400$ & $160-850$ & $190-300$ & $250-600$ & $150-400$ & $710-1400$ \\
\hline
\end{tabular}

\subsection{Relative density of LECA}

The particle density of an aggregate is the ratio between the mass of the particle material and the volume occupied by the individual particles. This volume includes 
the pores within the particle, but does not include voids between the particles. In general, the volume of the particles is determined from the volume displaced while submerged in water. Penetration of water into the aggregate particles during the test is limited by the aggregate's ceramic like matrix which inhibits water absorption particularly to the interior vesicles. The oven-dry density of an individual particle depends both on the density of the solid vitreous material and the pore volume within the particles, and generally increases when particle size decreases. The test conducted based on BS 1377: Part 2:1990:8 to define the specific gravity or relative density of light weight aggregate. The specific gravity values of the LECA aggregates were found to be lower than normal aggregates, which means that the material is floating on the water. Maximum and minimum void ratio reported are 1.628 and 1.894 , respectively.

\subsection{Water absorption characteristic}

According to the tests conducted, it is verified that the expanded clay shows high water absorption in relation to conventional aggregates. This high water absorption is related to the porous structure of its grains. Based on a 24-hour absorption test conducted in accordance with the procedures of ASTM C127 and ASTM C128, LECA aggregates will absorb 30 percent (30\%) moisture by mass of dry aggregate. By contrast, ordinary aggregates generally absorb less than 2 percent of moisture. This characteristic is in good agreement with performed research on absorption properties of expanded shale and clay aggregates where $24 \mathrm{~h}$ water absorption recorded from $6.0 \%$ to $30.5 \%[19,20]$. Table 2 illustrates the finding of physical properties of LECA conducted by previous researchers. [6, 9, 21, 22].

Table 2. Physical properties of LECA recorded from other studies

\begin{tabular}{|c|c|c|c|c|c|}
\hline Reference study & $\begin{array}{c}\text { Bulk } \\
\text { density } \\
\left(\mathbf{k g} / \mathbf{m}^{3}\right)\end{array}$ & $\begin{array}{l}\text { Specific } \\
\text { gravity }\end{array}$ & $\begin{array}{c}\text { Saturated } \\
\text { and } \\
\text { surface- } \\
\text { dried } \\
\text { particle } \\
\text { density, } \\
\mathrm{kg} / \mathrm{m}^{3}\end{array}$ & $\begin{array}{c}\text { Apparent } \\
\text { particle } \\
\text { density, } \\
\text { kg/m } \mathbf{m}^{3}\end{array}$ & $\begin{array}{c}\text { Absorption } \\
(\%)\end{array}$ \\
\hline $\begin{array}{l}\text { Rumsys, D. et al. } \\
\text { (2017) [21] }\end{array}$ & 488 & - & 1002 & 804 & 25 \\
\hline $\begin{array}{l}\text { Wu T. et al. } \\
(2016)[9]\end{array}$ & 663 & - & - & 1174 & 10 \\
\hline $\begin{array}{l}\text { Ardakani, A. \& } \\
\text { M. Yazdani } \\
(2014)[6]\end{array}$ & 257 & 0.481 & - & - & 26 \\
\hline $\begin{array}{l}\text { Siamak } \\
\text { Boudaghpour, } \\
\text { S.H. (2008) [22] }\end{array}$ & 400 & - & - & - & 17 \\
\hline
\end{tabular}




\begin{tabular}{|l|l|l|l|l|l|}
\hline This study & 293 & 0.45 & 1004 & 1005 & 30 \\
\hline
\end{tabular}

The important distinction in stockpile moisture content is that with lightweight aggregates the moisture is largely absorbed into the interior of the particles, whereas with ordinary aggregates it is primarily surface moisture. Rate of absorption is unique to each lightweight aggregate, and is dependent on the characteristics of pore size, continuity, and distribution, particularly for those pores close to the surface. According to T.A. Holm \& A.J. Valsangkar (2001), when LWAs are continuously submerged will continue to absorb water over time. The effective specific gravity of a submerged lightweight aggregate sample was measured throughout a one-year period to demonstrate long-term weight gain [23].

Saint Gobain Weber Ltd Laboratories performed long term tests on LECA using the BS EN 1097-6 "Tests for mechanical and physical properties of aggregates - Part 6: Determination of particle density and water absorption" test method. After 13 years (5000 days), the curves for LECA gradation 10 to $20 \mathrm{~mm}$ and 4 to $10 \mathrm{~mm}$ have not flattened indicating that the material is still absorbing water. Figure 3 illustrates the results visualised in a time - water absorption chart for LECA [24].

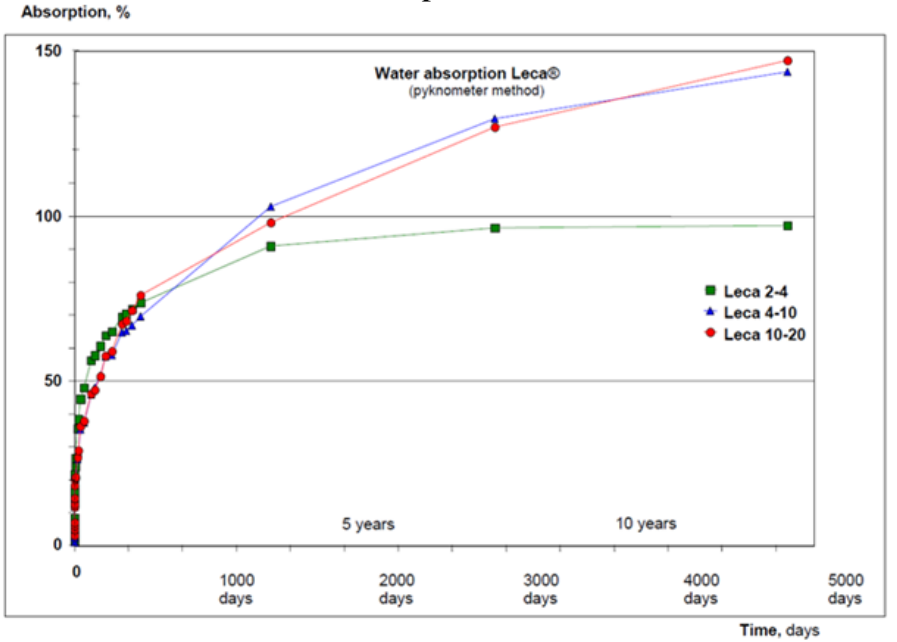

Fig. 3. Water Absorption against Time Chart for LECA (Source: LECA@UK)

\subsection{Permeability}

Permeability is the ability of the soil to allow the flow of water through the material. The voids in between the solid particles in soil are interconnected, allowing water to flow pass through them. There are several factors affecting the soil void system such as particle size distribution, particle size, particle shape and texture, void ratio, and mineralogical composition. The smaller the particles, the smaller the voids, thus creating more resistance to the water flow and therefore making the value of permeability low. The void ratio also has major influence on the permeability since it is dependent on how the soil is placed or compacted. Lightweight aggregate can be 
classified as granular material which produce a good drainage behaviour. LWA has superb water-draining properties, and because it is much lighter than any alternative materials such as gravel. Typical value of coefficient of permeability or hydraulic conductivity, $\mathrm{k}$ for clean gravel material is found to be 1 to $100 \mathrm{~cm} / \mathrm{s}$, while for course sand is 0.01 to $1 \mathrm{~cm} / \mathrm{s}$. Constant head test in accordance to ASTM D 2434 was chosen to determine the coefficient of permeability of LECA. This is because LECA aggregate is similar to coarse or granular materials. The permeability, $\mathrm{k}$ value for LECA determined in this study is $2.53 \mathrm{~cm} / \mathrm{s}$ based on maximum density of LECA (compacted).

\subsection{Compaction characteristics}

The main purpose for compaction test was to determine the relationship between moisture and the density. In this research, the Standard Proctor compaction test was carried out in accordance to BS 1377 Part 4: 1990. This test used 1 litre capacity mould and $2.5 \mathrm{~kg}$ hammer. Tests were conducted in a range of moisture contents assuming from $10 \%$ to $65 \%$. From the results, the graph dry unit weight versus moisture content was plotted to determine the maximum dry unit weight and corresponding optimum moisture content as represents in Figure 4. Maximum dry density and optimum moisture content determined from the test are $0.357 \mathrm{~g} / \mathrm{cm}^{3}$ and $24 \%$, respectively.

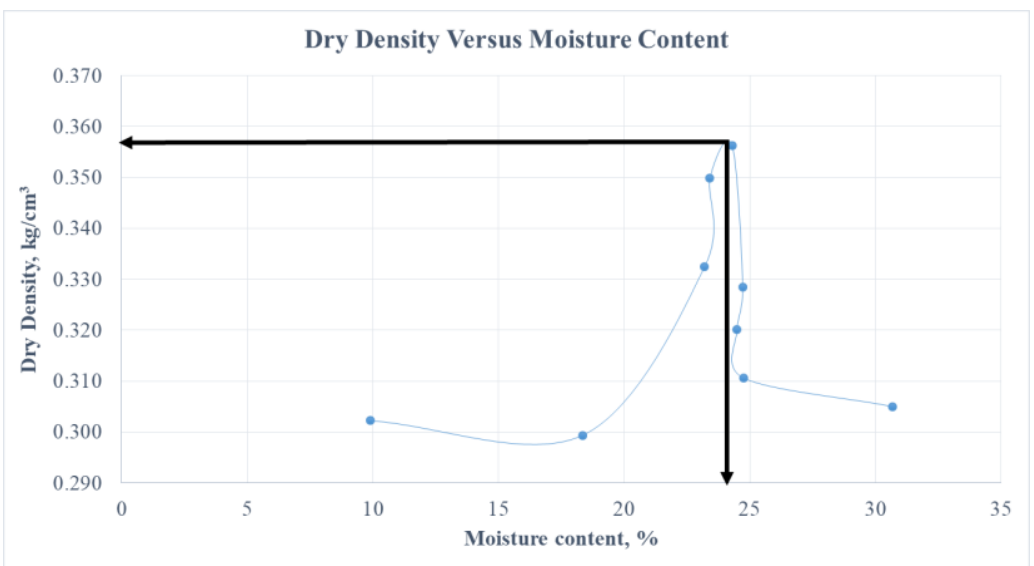

Fig. 4. Compaction Curve of LECA

\subsection{Chloride and Sulphate Content \& pH value}


LECA aggregate has a $\mathrm{pH}$ value of 9.5 which is shows that the material is alkali, while the measured of Chloride and Sulphate content are $6.5 \mathrm{mg} / \mathrm{L}$ and $95 \mathrm{mg} / \mathrm{L}$, respectively.

\section{Mechanical properties of LECA}

\subsection{Crushing strength}

The porous nature of the lightweight aggregate particles means that they have relatively low crushing strength compared to natural soil or rock particles. Because of the low crushing strength of the particles, lightweight aggregate is not recommended for use as an unbound sub-base, however it may be suitable for use as a capping layer where low values of sub grade CBR exist. Tests in large scale oedometers show that this aggregate has similar constrained modulus values to natural materials at low levels of stress, but that above a threshold value crushing of individual particles starts to occur and the modulus decreases. The threshold value was found to be about 100 $\mathrm{kN} / \mathrm{m}^{2}$ for the $10 \mathrm{~mm}$ to $20 \mathrm{~mm}$ material and $150 \mathrm{kN} / \mathrm{m}^{2}$ for the 0 to $32 \mathrm{~mm}$ material. LECA aggregate exhibits the maximum level of effective stress $100 \mathrm{kN} / \mathrm{m}^{2}$ to avoid crushing grains. While, the resistance to fragmentation or crushing of LECA is found to be $0.8 \mathrm{~N} / \mathrm{mm}^{2}$ as determined by Saint Gobain Weber Ltd laboratories using the BS EN13055-1 test method.

Combining Joisel's and Griffith's conclusions, Marsal (1969) suggested the following empirical correlation between the average crushing load, $\mathrm{Pa}$, obtained via laboratory crushing tests and the dimension, $\mathrm{D}$ of the particle; $\mathrm{P}_{\mathrm{a}}=\eta \mathrm{D}^{\lambda}$. The experimental data collected revealed an almost linear relationship between crushing load and particle diameter (Figure 5), with values $\eta=7.95$ and $\lambda=1.0$, showing no significant influence of the RH [25].

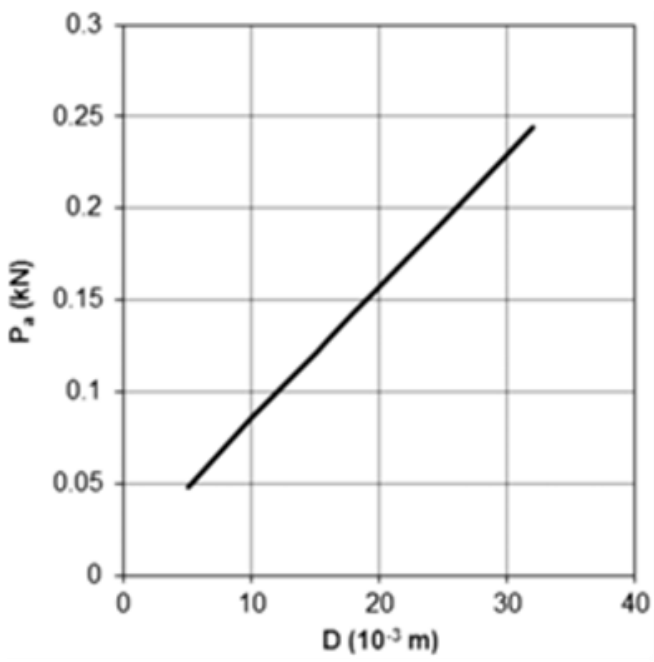


Fig. 5: Averaged crushing test results

While, the study conducted by Laura Maria Mello Saraiva Caldeira (2015) investigated mechanical characterization of lightweight expanded clay aggregate materials for modelling their geotechnical behaviour. From the laboratory works performed on lightweight expanded clay aggregate material with two different grainsize distributions and water content conditions, the quantification of nonlinear stiffness, internal friction angle, and its dependency on normal effective stresses and $\mathrm{K}_{0}$ have been determined which is can be used for civil engineering design [25].

The crushing resistant of LECA were also investigated by Markus Bernhardt et al. (2013) applying the European standard crushing resistance test (CR-test) as well as the single pellet compression test on more than 550 samples [26]. The crushing resistant, $C$ of LECA can be estimated using the equations developed;

$$
\begin{gathered}
C=F_{\text {crit }} / D^{2} \times 0.74 \\
\sigma_{\text {crit }}=F_{\text {crit }} / D^{2}
\end{gathered}
$$

Where, $\sigma_{\text {crit }}$ is a porosity independent strength, $\mathrm{d}$ the solid diameter (assuming zero porosity), $F_{\text {crit }}$ is the measured load at failure and $D$ is LECA diameter. The value of $F_{\text {crit }}$ may be predicted from Figure 6, while d value can be referred to Figure 7.

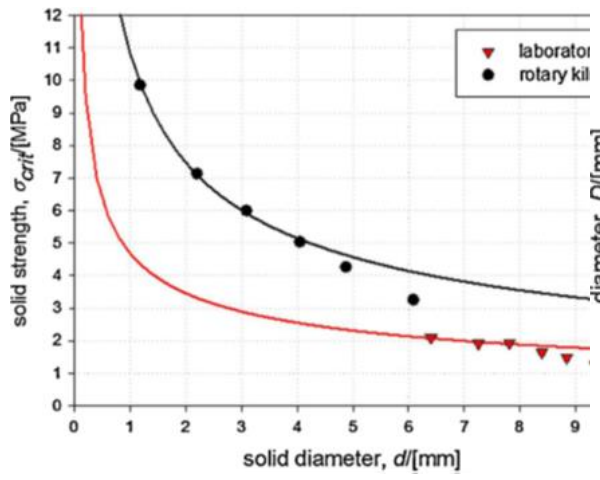

Fig. 6. Solid strength, $\sigma_{\text {crit }}$, as a function of the solid diameter, $\mathrm{d}$, for all samples.

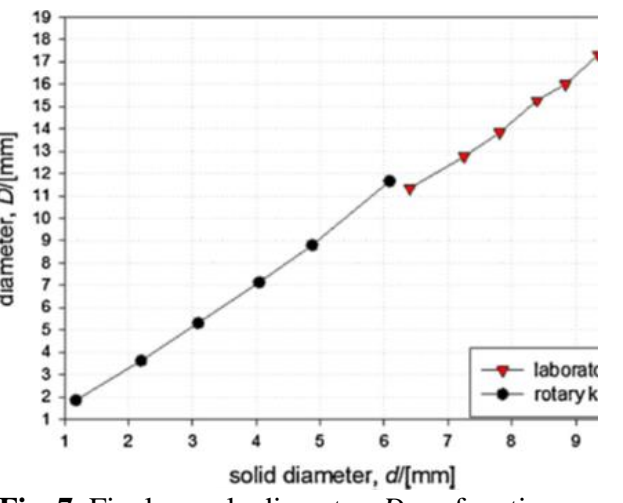

Fig. 7. Final sample diameter, $D$, as function of the solid diameter, $d$.

Particles breakage percentage of LECA in term of mass and volume have been determined after triaxial test completed, where the mass and volume tested samples before and after drying were recorded. The percentage of particles breakage in term of mass and volume are $32 \%$ and $34 \%$, respectively. From the test conducted in this study and the previous research, the crushing resistant and particle breakage of LECA for grains 10 to $20 \mathrm{~mm}$ can be seen in Table 4 below. The studies also show crushing 
associated with loading, as is usual in particulate materials. Crushing has a deleterious effect in the shear strength but improves stiffness. The point load test also has been conducted in this study to estimate the crushing value of LECA grains and the graph is shown in Figure 8.

Table 4. Crushing resistant and particle breakage of LECA

\begin{tabular}{|c|c|c|c|c|c|c|c|c|c|}
\hline Finding & This study & {$[25]$} & {$[22]$} & {$[21]$} & {$[9]$} & {$[6]$} & {$[24]$} \\
\hline \multirow{2}{*}{\begin{tabular}{c} 
Crushing resistant \\
\cline { 2 - 9 }
\end{tabular}} & 0.36 & 0.14 & 2.0 & 3.49 & 5.6 & 0.82 & 1.8 \\
\hline $\begin{array}{c}\text { Particle breakage } \\
\text { (Triaxial test) }\end{array}$ & $34 \%$ & $34 \%$ & - & - & - & - & - \\
\hline & & & & & & & \\
\hline
\end{tabular}

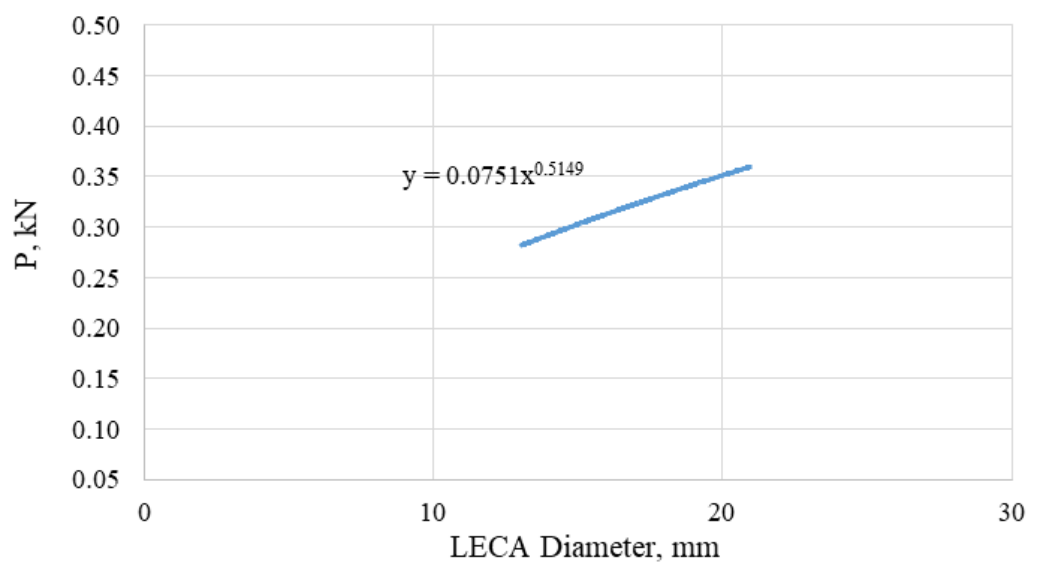

Fig. 8. Averaged point load test results

\subsection{Consolidated Undrained (CU) Triaxial Test}

Shear strength of soil is a parameter to determine the capability of soil to resist loading without failing. The preference of triaxial test over direct shear test is because triaxial test has many advantages where the test represents almost similar conditions where unlike direct shear test; the failure plane is caused naturally without being forced by the apparatus itself. The main objective of CU (consolidated undrained) test is to determine the increase in shear strength of LECA. The test was conducted according to BS 1377: Part 7: 1990: 3.

\subsubsection{Sample preparation}

The triaxial apparatus is one of the most widely used devices to evaluate the shear strength parameter. In triaxial testing, the sample-size ratio can be defined as the ratio (d/Dmax) of specimen diameter to maximum particle size (Vallerga et al. 1957, 
Marachi 1969, Indraratna 1993). The use of sample-size ratios smaller than five has been used to introduce testing errors due to particle size effects (Marsal 1969, Leslie 1969, Nitchiporovitch et al. 1969) especially when more than $30 \%$ of the sample is retained on the largest sieve size (Marachi 1969). Use of a minimum sample-size ratio of six, as recommended by ASTM D4767, leads to a maximum particle size of $12 \mathrm{~mm}$ for a $70 \mathrm{~mm}$ diameter specimen [27].

A maximum particle size of $12 \mathrm{~mm}$ may represent a small portion of geomaterials with large particle sizes such as mine waste rock, rockfill, and coarse aggregates. For CU test undertaken in this research, the cylindrical $100 \mathrm{~mm}$ in diameter and $200 \mathrm{~mm}$ in length samples were subjected to three phases which were saturation, consolidation and shearing with cell pressure applied 50, 100 and $200 \mathrm{kPa}$. Figure 9a shows the remoulded sample ready for testing, while Figure $9 \mathrm{~b}$ is the setup of the CU test conducted in Geotechnical Laboratory, UTM, while Figure 9c represents the Mohr Coulomb plot. Table 5 represents the strength properties and related test conducted on varies lightweight aggregates.

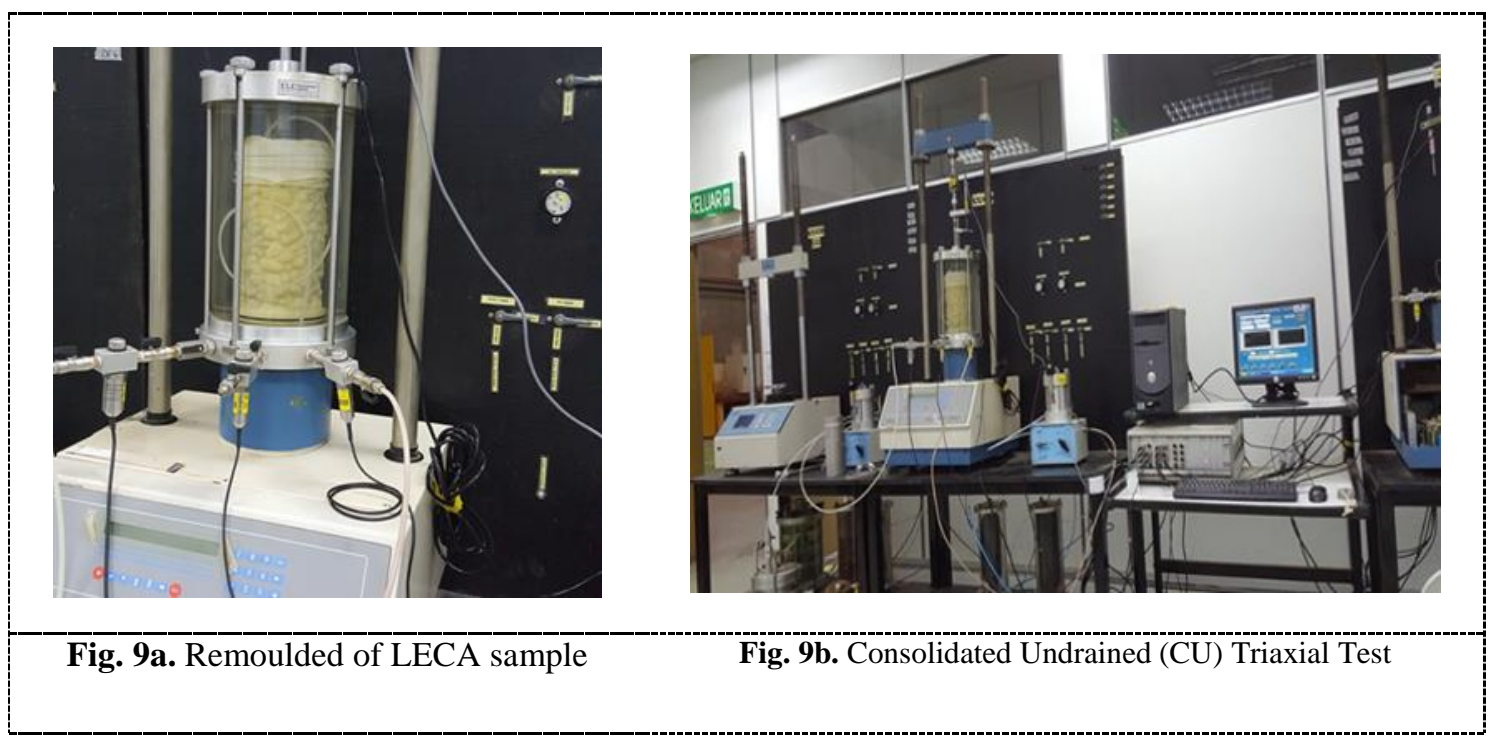




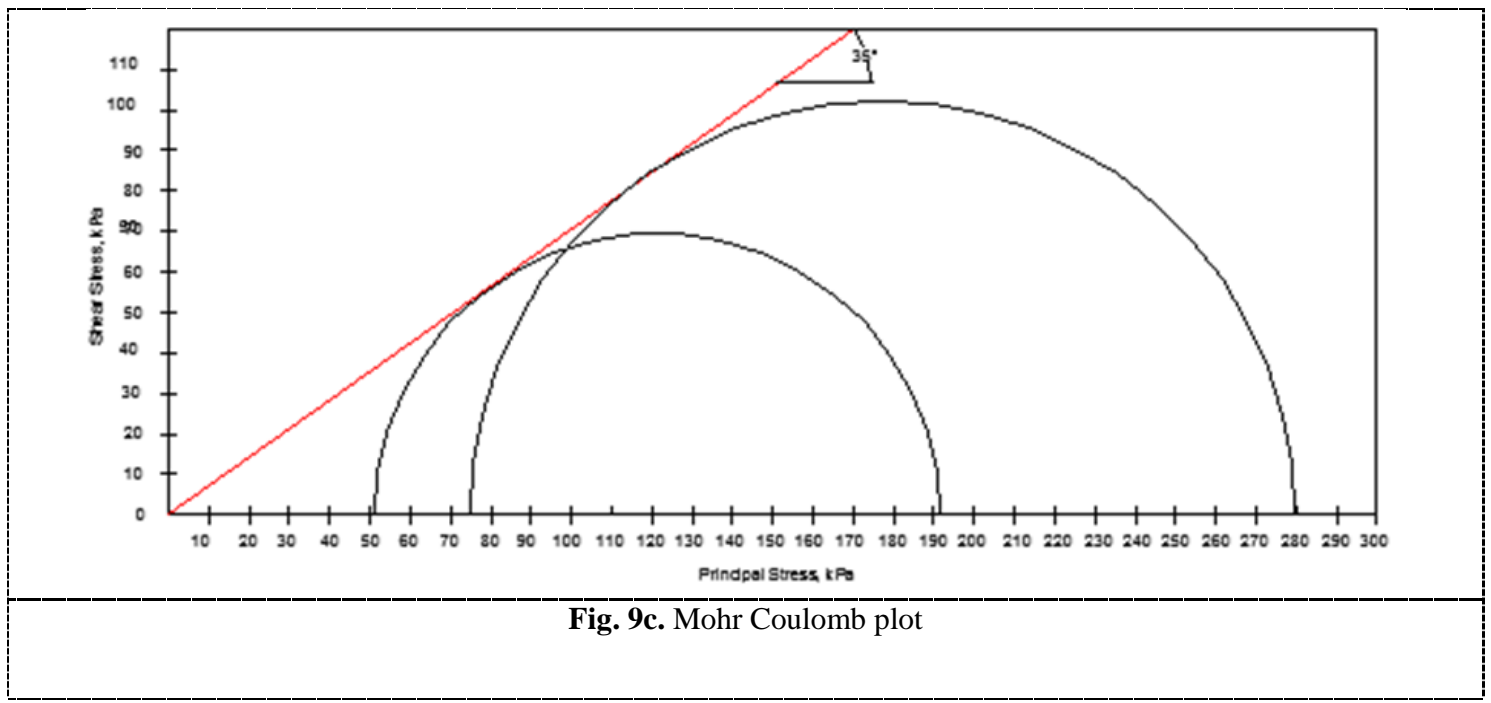

Table 5: Strength properties and test on varies lightweight aggregates

\begin{tabular}{|c|c|c|c|}
\hline $\begin{array}{l}\text { Lightweight aggregates } \\
\text { commercial name }\end{array}$ & Test & Gradation/Size & $\begin{array}{c}\text { Internal } \\
\text { Friction Angle }\end{array}$ \\
\hline Argex & $*$ & $*$ & $35^{\circ}$ to $42^{\circ}$ \\
\hline \multirow{2}{*}{ Optiroc } & \multirow{2}{*}{ Static triaxial test } & 10 to $20 \mathrm{~mm}$ & $37^{\circ}$ \\
\hline & & 0 to $32 \mathrm{~mm}$ & $45^{\circ}$ \\
\hline \multirow[b]{2}{*}{ ESCS } & Direct Shear Test & \multirow[b]{2}{*}{10 to $20 \mathrm{~mm}$} & \multirow[b]{2}{*}{$35^{\circ}-45^{\circ}$} \\
\hline & $\begin{array}{c}\text { Triaxial- Consolidated } \\
\text { Drained }\end{array}$ & & \\
\hline LECA & $\begin{array}{c}\text { Triaxial- Consolidated } \\
\text { Undrained } \\
\end{array}$ & 10 to $20 \mathrm{~mm}$ & $35^{\circ}$ \\
\hline \multirow[b]{2}{*}{ Stalite } & Direct Shear Test & \multirow[b]{2}{*}{10 to $20 \mathrm{~mm}$} & \multirow[b]{2}{*}{$43^{\circ}-46^{\circ}$} \\
\hline & $\begin{array}{c}\text { Triaxial- Consolidated } \\
\text { Drained } \\
\end{array}$ & & \\
\hline Norlite & $\begin{array}{l}\text { Triaxial-Consolidated } \\
\text { Drained }\end{array}$ & 10 to $20 \mathrm{~mm}$ & $42^{\circ}-53^{\circ}$ \\
\hline Minto & Large scale Triaxial test & $*$ & $40.5^{\circ}$ \\
\hline Solite & Large scale Triaxial test & $*$ & $40^{\circ}$ \\
\hline
\end{tabular}

*Not mentioned 


\subsubsection{Elastic Modulus, E of LECA}

The elastic modulus of LECA was determined by the micro mechanics method where the Mori-Tanaka model has been used in the study conducted by Alireza Ardakani \& Mahmoud Yazdani (2014). Based on results obtained the average elastic modulus for common and structural LECAs are 0.57 to 2.31 and 2.66 to $6.27 \mathrm{GPa}$, respectively; and there is a linear relation between the elastic modulus and the particle density of lightweight expanded clay aggregates. Their elastic modulus exponentially decreases with the increase in particle size. The equation for the determination of the elastic modulus of LECA was introduced;

$$
E_{G P a}=8.96 \rho_{t o n / m}{ }^{3}-3.78
$$

where $\rho_{\text {ton }} / \mathrm{m}^{3}$ is particle dry density of LECA [6]. From the study, the elastic modulus value of common LECA was found to be $(2431 \mathrm{kPa})$. From the equation established by the researcher, Elastic modulus value determined for LECA in this study is 0.00252 $\mathrm{GPa}$ or $2520 \mathrm{kPa}$. However, study conducted by HJ Chen et al. (2003) the value determined was $6.80 \mathrm{GPa}$ [28]. The findings shows that the elastic modulus value of LECA were varies depending on the production process.

\section{Conclusion}

Lightweight expanded clay aggregates (LECA) are one type of artificial lightweight aggregates which have wide application and become famous material used in civil engineering works. LECA has specific properties which can be applied as a suitable material in structural and geotechnical application. LECA has been used successfully to produce lightweight concrete structure, as lightweight fill, drainage and insulation materials in embankments for roads, railways and other traffic areas, as lightweight backfill for retaining walls or as foundation for structures and agricultures. The properties of LECA shows that it can be used for replacing natural aggregates in many civil engineering works.

From the review on previous findings shows that different LECA will give various properties depending on the chemical compositions and the production process. However, the properties of the LECA from different production are not much different from each other where the values are still within a certain range. The properties of LECA can be summarized as presented in Table 6 below. These physical and mechanical properties of LECA can be used in the design of civil engineering works. This study also offers relevant support for the development of constitutive models in numerical analysis. In terms of stress-strain behaviour, the material can be considered as a work hardening (negative dilation) material despite the very low confining pressures applied. In addition, Mohr Columnb constitutive model also can be used to represent the behaviour of LECA granular material in numerical analysis. 


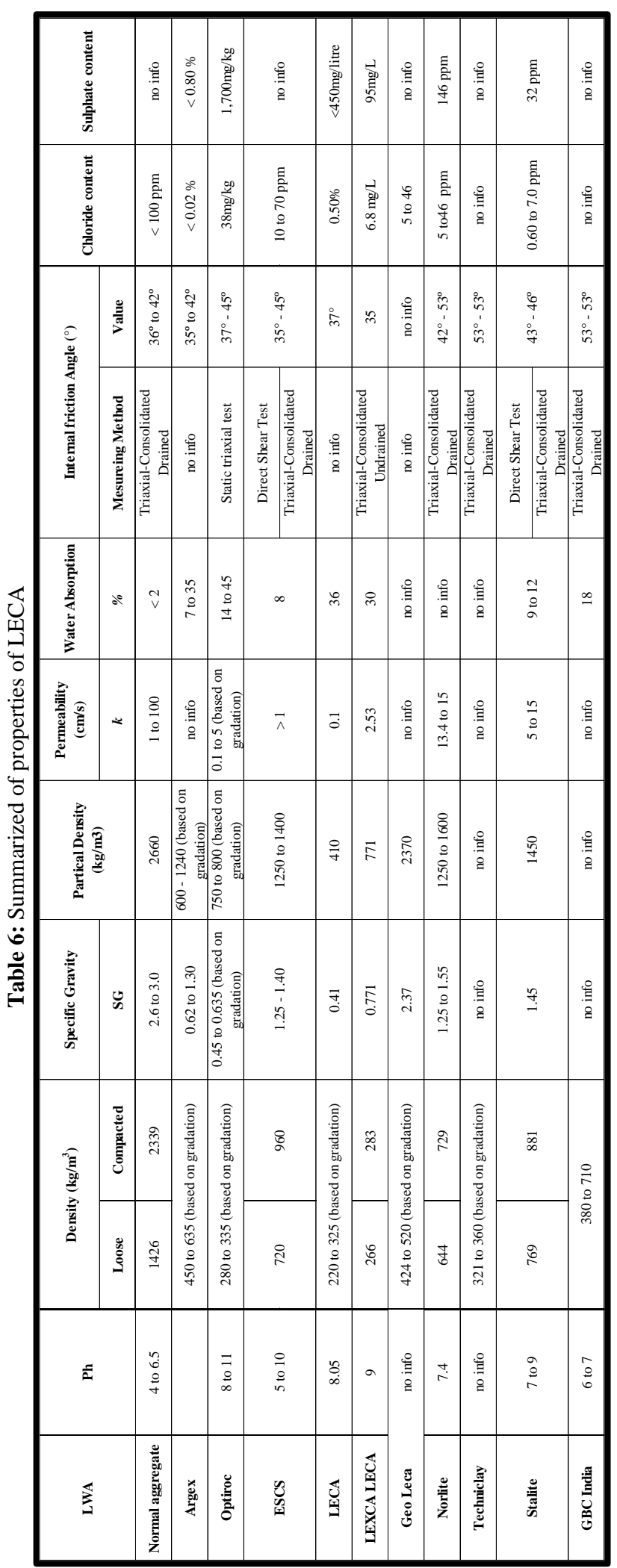




\section{Acknowledgement}

The authors wishes to thanks to Universiti Teknologi Malaysia for providing facilities during the research work.

\section{References}

1. Holm T A and Valsangkar A J Lightweight Aggregate Soil mechanics: Properties and Applications (Transportation Research Record), (1993)

2. Parmar A, Patel U, Vaghashiya A, Parmar A and Parmar P Fresh concrete properties of light weight concrete using EPS and LECA as a replacement of normal aggregates International Journal of Engineering Development and Research 4 663-6, (2016)

3. Bogas J A, Gomes A and Gomes M G Estimation of water absorbed by expanding clay aggregates during structural lightweight concrete production Materials and Structures 45 1565-76, (2012).

4. Domagała L The Effect of Lightweight Aggregate Water Absorption on the Reduction of Water-cement Ratio in Fresh Concrete Procedia Engineering 108 206-13

5. Aslam M, Shafigh P and Jumaat M Z High Strength Lightweight Aggregate Concrete using Blended Coarse Lightweight Aggregate Origin from Palm Oil Industry Sains Malaysia 46 667-75

6. Ardakani A and Yazdani M The relation between particle density and static elastic moduli of lightweight expanded clay aggregates Applied Clay Science 93-94 28-34

7. Shafigh P, Ghafari H, Mahmud H Bin and Jumaat M Z A comparison study of the mechanical properties and drying shrinkage of oil palm shell and expanded clay lightweight aggregate concretes Materials \& Design 60 320-7, (2014).

8. Dilli M E, Atahan H N and Şengül C A comparison of strength and elastic properties between conventional and lightweight structural concretes designed with expanded clay aggregates Construction and Building Materials 101 260-7, (2015).

9. Wu T, Wei H, Liu X and Xing G Factor Influencing the mechanical properties of lightweight aggregates concrete Indian Journal of Engineering and Material Sciences 23 301-11, (2016).

10. Schackow A, Effting C, Folgueras M V, Güths S and Mendes G A Mechanical and thermal properties of lightweight concretes with vermiculite and EPS using air-entraining agent Construction and Building Materials 57 190-7, (2014).

11. Bodnárová L, Hela R, Hubertová M and Nováková I Behaviour of Lightweight Expanded Clay Aggregate Concrete Exposed to High Temperatures International Science Index, Civil and Environmental Engineering 1, 2014 498, (2014).

12. C. Munoz-Ruiperez S. Gutierrez-Gonzalez, V. Calderon A R Lightweight masonry mortars made with expanded clay and recycled aggregates Construction and Building Materials 118 139-145, (2016).

13. Valsangkar A . and Holm T A 1987 M o d e 1 Tests on Peat - Geotextile - L i g h t w e i g h t Aggregate $\mathrm{S}$ y s t e m Geotextiles and Geomembranes 5 251-60

14. Górniak J, Villard P, Barral C, Delmas P and Watn A Experimental and analytical studies of geosynthetic tubes filled with expanded clay lightweight aggregate Geosynthetics International 22 23548, (2015).

15. Xiao M, Tehrani F and Zoghi M Seismic Responses of MSE Walls Using Accelerated Alternative Backfill Materials with Recycled Tire Shreds and Lightweight Expanded Aggregates (STATE OF CALIFORNIA: Department Of Transportation), (2013)

16. Arioz O, Kilinc K, Karasu B, Kaya G, Arslan G, Tuncan M, Tuncan A, Korkut M and Kivrak S A preliminary research on the properties of lightweight expanded clay aggregate Journal of the Australian Ceramic Society 44 23-40, (2008).

17. Khafaji S K T and Al-Majed E A Synthesis-of-Light-expanded-clay-aggregates-from-Iraqi-rawmaterials International Journal of Scientific and Engineering Research (IJSER) 7 690-6, (2016).

18. A. Mueller S N S and V I V Characteristics of lightweight aggregates from primary and recycled raw materials Construction and Building Materials 22 703-712, (2008).

19. Moravia W G, Oliveira C A S, Gumieri A G and Vasconcelos W L Caracterização microestrutural da argila expandida para aplicação como agregado em concreto estrutural leve Cerâmica 52 193-9, (2006).

20. Castro J, Keiser L, Golias M and Weiss J Absorption and desorption properties of fine lightweight aggregate for application to internally cured concrete mixtures Cement and Concrete Composites $\mathbf{3 3}$ 1001-8, (2011). 
21. Rumšys D, Bačinskas D, Spudulis E and Meškènas A Comparison of Material Properties of Lightweight Concrete with Recycled Polyethylene and Expanded Clay Aggregates Procedia Engineering 172 937-44 (2017).

22. Siamak Boudaghpour S H A Study on Light Expended Clay Aggregate (LECA) in a Geotechnical View and its Application on Greenhouse and Greenroof Cultivation INTERNATIONAL JOURNAL OF GEOLOGY 2 59-63 (2008).

23. Valsangkar T A H and A J Lightweight Aggregate Soil Mechanics: Properties and Application (Expanded Shale, Clay and Slate Institute), (2001)

24. Anon <Working with Leca® LWA and Water (2010).pdf>

25. Caldeira L M M S and Neves E M das Mechanical Characterization of Lightweight Expanded Clay Aggregate Materials for Modeling Their Geotechnical Behavior Journal of Materials in Civil Engineering 2704015027 (2015).

26. Bernhardt M, Tellesbø H, Justnes H and Wiik K Mechanical properties of lightweight aggregates Journal of the European Ceramic Society 33 2731-43

27. Fox Z, Antonio J and Carraro H Peak and critical-state shear strength of mine waste rock Tailings and Mine Waste 2010 pp 79-90, (2010).

28. Chen H J, Yen T and Chen K H Evaluating elastic modulus of lightweight aggregate ACI Materials Journal 100 108-13 (2003). 